\title{
PETA KAJIAN PENDIDIKAN ISLAM PADA BERKALA ILMIAH DI IAIN MATARAM
}

\author{
Saparudin \\ Instiut Agama Islam Negeri (IAIN) Mataram \\ J1. Pendidikan No. 35 Mataram \\ Email: sapar.saparudin@ymail.com
}

\begin{abstract}
Abstrak: Jumlah publikasi ilmiah yang terus meningkat, terutama bidang kependidikan Islam, di satu sisi dapat dijadikan indikator dinamika intelektual yang tinggi di lingkungan IAIN Mataram. Namun di sisi lain, peta dinamika tersebut belum terbaca secara jelas, baik pada aspek objek kajiannya, pendekatan yang digunakan, maupun jenis studi yang dilakukan. Kondisi ini, dapat berimplikasi terhadap ketidakjelasan arah dan kebijakan pengembangan keilmuan kependidikan Islam. Mendalami hal tersebut, metode yang digunakan adalah penelitian kepustakaan (library research), dengan contents analysis. Hasil penelitian menunjukkan: pertama, dari aspek objek studi, kajian pendidikan Islam pada berkala ilmiah di IAIN Mataram mencerminkan dominannya aspek filsafat atau pemikiran pendidikan Islam sebagai objek kajian; Kedua, sejalan dengan objek kajiannya, dari segi jenis studi, konsep pendidikan Islam yang dipublikasikan pada berkala ilmiah di IAIN Mataram, menunjukkan masih kuatnya kecenderungan kajian teoritis, disusul penelitian lapangan (field reseach), dan kajian pustaka (library reseach); dan Ketiga, paralel dengan kedua aspek di atas, dilihat dari segi pendekatan yang digunakan, kecenderungan pola kajian pendidikan Islam dosen IAIN Mataram, dapat dipilah dalam beberapa corak: (a). Corak pragmatis, baik yang bersifat adoftif maupun justifikatif, (b) corak Idealis, yaitu kajian yang menempatkan al-Qur'an dan Hadits dan pemikiran klasik dalam posisi yang lebih unggul untuk menjelaskan (bukan menjawab) sejumlah aspek/persoalan pendidikan Islam; (c) corak eklektif (gabungan dari corak idealis dan corak pragmatis); dan (d) corak deskriptif empiris.
\end{abstract}

\begin{abstract}
The amount of research publication has been increasing, especially in Islam education area, in one side it can be made by high intellectual dynamics indicator in IAIN Mataram. But on the other side, map of the dynamics isn't yet read clearly in study object aspect, used approach, and also conducted study type. This condition, can implicate its direction and policy of development the Islamic education. To comprehend the mentioned, the method used is bibliography research (research library), include the analysis contents. Result of research show: firstly, object study aspect, study of Islamic education at periodically in IAIN Mataram which dominant express the philosophy aspect or idea of education of Islam as study object; secondly, its study object, from study type, the concept Islamic education has publicized Islam is periodically in IAIN Mataram, showing still its strength in theoretical study, include the field research, and library research; Third, parallel both aspect above, showing from applied the study approach, the tendency of study pattern education of Islam the lecturer of IAIN Mataram, can divide in a few pattern: (a) Pragmatic pattern, for having the adoptive character and also justificative; ( b) Idealist pattern, the study of al-Qur'an and Hadits and classic idea in more pre-eminent position to explain (non replying) a number of aspect / problem of Islamic education Islam; (c) Elective pattern (alliance of idealist pattern and pragmatic pattern); and (d) Empiric descriptive pattern.
\end{abstract}

Kata kunci: peta konsep, publikasi ilmiah, pendidikan Islam, jurnal 


\section{PENDAHULUAN}

Para ilmuan mengatakan "pengetahuan individu akan memasuki domain ilmu pengetahuan hanya setelah ilmu tersebut, dipresentasikan, dipublikasikan, dan atau direview secara independen oleh ilmuan lain yang kompeten". ${ }^{1}$ Bagi perguruan tinggi, pernyataan ini diterjemahkan dalam bentuk publikasi karya ilmiah para dosen. Publikasi ilmiah merupakan bagian penting dari nafas kehidupan perguruan tinggi. Kini, berkualitas tidaknya suatu perguruan tinggi dinilai dari seberapa banyak penelitian dan publikasi ilmiah dihadirkan. Relevan, karena salah satu fungsi berkala ilmiah menurut Nur Kholis, adalah mempromosikan reputasi perguruan tinggi, ${ }^{2}$ disamping meregistrasi kegiatan kecendikiaan, menyertifikasi hasil kegiatan yang memenuhi persyaratan ilmiah, mendesiminasikannya secara meluas kepada khalayak ramai, dan mengarsipkan semua temuan hasil kegiatan kecendikiaan ilmuan dan pandit yang dimuatnya. ${ }^{3}$

Mewadahi kepentingan tersebut, keberadaan berkala ilmiah sebagai bentuk pemberitaan atau komunikasi yang memuat karya ilmiah dan diterbitkan secara berjadwal dalam bentuk tercetak dan/atau elektronik ${ }^{4}$ mutlak diperlukan. Tradisi ilmiah berupa penerbitan jurnal ilmiah menurut Robby Hidayat memiliki sumbangan yang positif, yakni membangun tradisi ilmiah; sebagai indikator aktivitas keberadaan insan akademik. Kehadiran jurnal memberikan kontribusi positif utamanya dalam dan bagi pengembangan disiplin akademik di bidang ilmu pengetahuan, teknologi dan seni. ${ }^{5}$ Melalui karya-karya ilmiah yang dipublikasikan, pengujian dan aplikasi keilmuan dapat diwujudkan dan disebarluaskan ke publik.

Menyadari pentingnya publikasi ilmiah melalui wadah berkala ilmiah, maka sejak tahun 2007, IAIN Mataram mengeluarkan kebijakan yang mengharuskan setiap jurusan menerbitkan jurnal ilmiah, untuk menambahkan berkala ilmiah yang lebih awal terbit di tingkat institut, fakultas dan unit. Kebijakan ini sebagaimana di utarakan Pembantu Rektor I, H.M. Taufik, dimaksudkan untuk memperluas ruang desiminasi dan publikasi karya ilmiah para dosen di lingkungan IAIN Mataram. ${ }^{6}$ Hingga saat ini, jumlah berkala ilmiah di lingkungan IAIN

\footnotetext{
${ }^{1}$ Triwulan, Materi Dasar Penulisan Jurnal Ilmiah, disampaikan pada PENLOK Penelitian Dosen Muda dan Kajian Wanita, di Mataram, DP2M, 2006

${ }^{2}$ M.Nur Kholis Setiawan, Etika Terbitan Berkala Ilmiah, Makalah disampaikan pada Penataran dan Lokakarya Manajemen Berkala Ilmiah, di Yogyakarta, 2011. h. 4

${ }^{3}$ Permendiknas No. 22 tahun 2011, Tentang Terbitan Berkala Ilmiah, pasal 3

${ }^{4}$ Ibid. Pasal 1

${ }^{5}$ Robby Hidayat, Heuristik Penulisan Artikel Seni dan Desain dalam Jurnal, Makalah Semiloka dan Pameran Nasional Strategi Penerbitan Jurnal Nasional Bidang Seni dan Desain, Universitas Negeri, 2001.

${ }^{6}$ H.M. Taufik, Kebijakan Pengembangan Berkala Ilmiah di IAIN Mataram, Makalah disampaikan pada Lokakarya Peningkatan Mutu dan Penyuntingan Berkala Ilmiah, Jurnal Penelitian Keislaman IAIN Mataram, 2011
} 
Mataram adalah 20 Jurnal, yang tersebar di tingkat institut, fakultas, jurusan dan unit-unit. Dengan frekuensi terbit dua kali setiap tahun masing-masing jurnal, maka ada 40 edisi Jurnal yang beredar tiap tahunnya.

Banyaknya jurnal tersebut berdampak terhadap jumlah artikel dosen yang berhasil dipublikasikan. Berdasarkan hasil survey awal, jumlah artikel yang dimuat pada Jurnal peredisi jika di rata-ratakan berkisar antara 7-8 artikel. Jumlah ini jika dihubungkan dengan jumlah jurnal yang ada, maka setiap edisi, jumlah rata-rata artikel yang dimuat berkisar ant ara 140-160 artikel. Hal ini berarti jumlah artikel yang dipublikasikan pada setiap tahunnya (dua edisi) berkisar 280- 320 artikel, dan tidak kurang dari $75 \%$ di tulis oleh dosen IAIN Mataram.

Dilihat dari substansi keilmuan, sebagian besar berkala ilmiah di atas memuat artikel kependidikan Islam dalam berbagai aspeknya. Relevan, mengingat 7 dari 20 jurnal di atas, merupakan berkala ilmiah dengan spesifikasi bidang kependidikan. Hal ini sebagai implikasi dari keberadaan Fakultas Tarbiyah sebagai fakultas terbesar, baik secara kelembagaan maupun jumlah dosen yang dimiliki. Pada saat yang bersamaan, disamping dimuat pada 7 berkala ilmiah tersebut, hasil-hasil kajian bidang kependidikan Islam, juga dimuat pada berkalah ilmiah lainnya dengan ruang yang variatif. Konsep pendidikan Islam yang dimaksud adalah hasil pemikiran, perenungan, interpretasi, dan studi empiris para dosen IAIN Mataram yang diinspirasikan dari al-Qur'an dan As-Sunnah, proses dan praktik pendidikan Islam, baik dalam payung ontologi, epistimologi, dan askiologi pendidikan Islam.

Jumlah publikasi ilmiah yang demikian besar di atas, terutama bidang kependidikan Islam, di satu sisi dapat dijadikan indikator dinamika intelektual yang tinggi di lingkungan IAIN Mataram. Namun di sisi lain, peta dinamika tersebut belum terbaca secara jelas, baik pada aspek objek kajiannya, pendekat an yang digunakan, maupun jenis studi yang dilakukan. Kondisi ini, dapat berimplikasi terhadap ketidakjelasan arah dan kebijakan pengembangan keilmuan kependidikan Islam di satu sisi, dan berkalah ilmiah di sisi lain.

Berdasarkan kondisi empiris di atas, studi ini diarahkan untuk menjawab beberapa persoalan mendasar berkaitan dengan: pertama bagaimana peta konsep pendidikan Islam pada berkala ilmiah di lingkungan IAIN Mataram berdasarkan objek kajiannya (substansi). Rumusan ini dibatasi pada dua klasifikasi, yaitu konsep ilmu pendidikan Islam dalam konteks rumpun keilmuan (filsafat, psikologi, manajemen, dan sejarah pendidikan Islam), dan konsep pendidikan Islam dalam konteks sebagai sistem operasional pendidikan Islam (tujuan, kurikulum, metode, media, evaluasi, lembaga, pendidik, peserta didik, dan komponen operasional lainnya); Kedua, bagaimana peta konsep pendidikan Islam dilihat dari jenis studi yang dilakukan. Rumusan masalah ini dibatasi pada klasifikasi penelitian lapangan (field 
research), penelitian kepustakaan (library research), dan artikel ilmiah umum (survey literatur); dan ketiga, bagaimana peta konsep pendidikan Islam berdasarkan pendekatan yang digunakan. Hal ini dibatasi pada paradigma atau sudut pandang penulis terhadap objek yang dikaji, dalam rangka mengkonstruksi konsep pendidikan Islam berdasarkan realitas teoritik maupun empirik.

\section{METODE PENELITIAN}

Penelitian ini termasuk dalam kategori penelitian pustaka (library research). Pendekatan library research menjadikan teks atau dokumen sebagai objek kajian. Peneitian jenis ini relevan untuk mendalami tema dan atau kategori tertentu yang tertuang pada suatu teks, naskah atau narasi. ${ }^{7}$ Penggunaan pendekatan tersebut dalam studi ini adalah tepat, sebab data-datanya tersaji dalam bentuk data tertulis, berupa artikel ilmiah hasil kajian dalam bidang kependidikan Islam yang terpublikasi pada berkala ilmiah (jurnal) yang ada di lingkungan IAIN Mataram.

Disamping itu, sejalan dengan pendapat Ardana dkk di atas, studi ini bertujuan untuk memetakan konsep pendidikan Islam berdasarkan sejumlah artikel ilmiah para dosen IAIN Mataram. Pemetaan tersebut dilakukan sesuai dengan kategori: kajian pendidikan Islam berdasarkan objek kajiannya, pendekatan yang digunakan, dan jenis studi yang dilakukan.

Data penelitian ini diperoleh dari seluruh berkala ilmiah (jurnal) yang ada di lingkungan IAIN Mataram yang memuat konsep pendidikan Islam. Mengingat berkala ilmiah diterbitkan setiap tahun, dengan jumlahnya yang mencapai ratusan, maka dibatasi pada berkala ilmiah yang terbit tiga tahun terakhir (antara tahun 2010 - 2012). Penentuan berkala ilmiah yang dijadikan sumber data dalam rentang tahun tersebut dipandang memadai untuk memotret berbagai objek, pendekatan, dan jenis studi dalam kajian pendidikan Islam. Dalam menentukannya, terlebih dahulu diidentifikasi secara terstruktur per-edisi, apakah suatu berkala ilmiah memuat artikel konsep pendidikan Islam atau tidak.

Sedangkan dari aspek penulis, dibatasi pada artikel yang ditulis oleh para dosen IAIN Mataram. Pembatasan ini sengaja dilakukan, agar signifikansi penelitian ini dapat secara sungguh-sungguh, mendalam dan utuh memotret dinamika keilmuan dan intelektual dosen IAIN Mataram berdasarkan publikasi ilmiah yang dihasilkan. Konsisten dengan sumber data ini, jenis data yang akan dikumpulkan dalam penelitian ini adalah data verbal, baik yang berkaitan dengan objek kajian pendidikan Islam, pendekatan yang digunakan, maupun jenis studi yang dilakukan, pada berkalah ilmiah tersebut.

\footnotetext{
${ }^{7}$ Ardana, dkk. Metodologi Penelitian Pendidikan, Malang, UMN, 2001, hal. 96
} 
Sesuai dengan pendekat an yang digunakan, dan karakter data yang akan diungkap, maka analisis yang akan digunakan adalah analisis isi atau content analysis. Analisis isi, sebagaimana diutarakan James H. McMillan dan Sally Schumacher, analisis isi termasuk salah satu bentuk dari a conceptual analysis. ${ }^{8}$ Dalam pelaksanaannya, penulis akan menempuh tiga langkah sebagaimana yang dirumuskan Muhadjir. Menurut Muhadjir, ${ }^{9}$ dalam melakukan analisis isi ada tiga langkah yang ditempuh peneliti, yaitu: (1) menetapkan tema dan kata kunci yang dicari dalam dokumen yang akan diteliti dan dikaji, (2) memberi makna atas tema dan kata kunci tersebut, dan (3) melakukan interpretasi internal.

Sesuai pendapat tersebut, maka analisis data penelitian ini dilakukan dengan mengikuti tiga langkah berikut: pertama, menetapkan tema atau kategori. Dalam konteks penelitian ini tema atau kata kunci dimaksud berkenaan dengan konsep pendidikan Islam berdasarkan objek kajiannya, pendekat an yang digunakan, dan jenis studi yang dilakukan; Kedua, memberi makna terhadap berbagai konsep tersebut dengan cara mempelajari dan menelusuri objek kajian, pendekatan yang digunakan, dan jenis studi yang dilakukan, dalam sejumlah artikel ilmiah pada berkala ilmiah di lingkungan IAIN Mataram; dan Ketiga, melakukan pemetaan berdasarkan tema atau kategori tersebut.

Proses pemetaan di atas secara teknis dilakukukan dengan mengacu pada teknik analisis isi (content analysis) Krippendorff. ${ }^{10}$ yang berfokus pada: pertama analisis penunjukan (designation), yaitu menggambarkan frekuensi seberapa sering objek, pendekatan, dan jenis studi tertentu muncul dalam kajian pendidikan Islam pada sejumlah berkala ilmiah di lingkungan IAIN Mataram; Kedua, analisis penafsiran (attributions), yaitu pemaknaan terhadap aspek dominan diantara kategori konsep pendidikan Islam tersebut, dalam konteks dinamika keilmuan dosen di IAIN Mataram; dan Ketiga, analisis pernyataan (assertions), yaitu melakukan abstraksi berdasarkan hasil penafsiran dalam bentuk peta konsep yang telah dirumuskan. Dengan demikian, langkah analisis ini diharapkan dapat pemetaan secara utuh konsep pendidikan Islam pada berkala ilmiah di lingkungan IAIN Mataram, sesuai dengan fokus studi ini.

Untuk menjamin kesahihan data yang diperoleh, penelitian ini menggunakan teknik pencermatan kesahihan internal dan eksternal. Kesahihan internal dibangun melalui prosedur analisis yang menempatkan masing-masing unit data ke dalam kategorinya. Pada tahap ini

\footnotetext{
${ }^{8}$ James H. McMillan dan Sally Schumacher, Research in Education: A Conceptual Introduction, New York: Longman, 2001, 506.

${ }^{9}$ Noeng Muhadjir, Metodologi Penelitian Kualitatif, Yogyakarta: Rake Sarasin, 1995, 90-94.

${ }^{10}$ Klaus Krippendorff, Analisis Isi: Pengantar Teori dan Metodologi, terj. Farid Wajidi, cet. 2, Jakarta: Raja Grafindo Persada, 1993, 36.
} 
setiap data atau artikel dicek kembali, apakah sudah tepat dan relevan di masukkan dalam kategori tertentu atau tidak. Sedangkan kesahihan eksternal dibangun dengan cara mengkonsultasikan data dan temuan penelitian dengan teori berkenaan dengan tema yang diteliti. Pada tahap ini kerangka teori yang memuat peta konsep dan komponen pendidikan Islam, kembali didiskusikan dengan data yang diperoleh untuk memastikan relevansinya dengan pemetaan yang dilakukan. Untuk melengkapi dan mendukung kesahihan eksternal ini, seminar hasil penelitian penting dilakukan.

\section{HASIL DAN PEMBAHASAN}

\section{Perkembangan Berkala Ilmiah di IAIN Mataram}

Manifestasi tri dharma perguruan tinggi di IAIN Mataram pada aspek penelitian dan publikasi ilmiah kini semakin terasa. Untuk mewadahi hasil-hasil penelitian para dosen, sejak tahun 2007 IAIN Mataram mengeluarkan kebijakan yang mengharuskan setiap jurusan menerbitkan jurnal ilmiah, untuk menambahkan berkala ilmiah yang lebih awal terbit di tingkat institut, fakultas dan unit. Kebijakan ini sebagaimana di utarakan Pembantu Rektor I, H.M. Taufik, dimaksudkan untuk memperluas ruang desiminasi dan publikasi karya ilmiah para dosen di lingkungan IAIN Mataram. ${ }^{11}$ Hingga saat ini, jumlah berkala ilmiah di lingkungan IAIN Mataram adalah 19 Jurnal, yang tersebar di tingkat institut, fakultas, jurusan dan unit-unit. Dengan frekuensi terbit dua kali setiap tahun masing-masing jurnal, maka ada 40 edisi Jurnal yang beredar tiap tahunnya.

Banyaknya jurnal tersebut berdampak terhadap jumlah artikel dosen yang berhasil dipublikasikan. Berdasarkan hasil survey awal, jumlah artikel yang dimuat pada Jurnal peredisi jika di rata-ratakan berkisar antara 7-8 artikel. Jumlah ini jika dihubungkan dengan jumlah jurnal yang ada, maka setiap edisi, jumlah rata-rata artikel yang dimuat berkisar antara 140-160 artikel. Hal ini berarti jumlah artikel yang dipublikasikan pada setiap tahunnya (dua edisi) berkisar 280- 320 artikel, dan tidak kurang dari $75 \%$ di tulis oleh dosen IAIN Mataram.

Dilihat dari substansi keilmuan, sebagian besar berkala ilmiah di atas memuat artikel kependidikan Islam dalam berbagai aspeknya. Relevan, mengingat 7 dari 19 jurnal di atas, merupakan berkala ilmiah dengan spesifikasi bidang kependidikan. Hal ini sebagai implikasi dari keberadaan Fakultas Tarbiyah sebagai fakultas terbesar, baik secara kelembagaan maupun jumlah dosen yang dimiliki. Pada saat yang bersamaan, disamping dimuat pada 7 berkala

\footnotetext{
${ }^{11}$ H.M. Taufik, Kebijakan Pengembangan Berkala Ilmiah di IAIN Mataram, Makalah disampaikan pada Lokakarya Peningkatan Mutu dan Penyuntingan Berkala Ilmiah, Jurnal Penelitian Keislaman IAIN Mataram, 2011
} 
ilmiah tersebut, hasil-hasil kajian bidang kependidikan Islam, juga dimuat pada berkalah ilmiah lainnya dengan ruang yang variatif. Sebaran berkalah ilmiah, berikut fokus kajian masing-masing nampak pada sajian berikut:

Besarnya jumlah berkala ilmiah di atas, dengan keragaman fokus kajiannya, dapat menjadi salah satu indikator bahwa dinamika keilmuan di di lingkunagan IAIN Mataram. Namun demikian, memperhatikan tabel di atas, berkala ilmiah yang memperoleh status akreditasi hanya satu jurnal dari 19 jurnal yang ada di lingkungan IAIN Mataram, yaitu jurnal Ulumuna yang pengelolaannya di tingkat Institut. Sementara Jurnal Penelitian Keislaman yang dikelola Lembaga Penelitian tidak berhasil memperpanjang stat us akreditasinya, yang disandangnya dari tahun 2008 hingga 2011. Bahkan jurnal Kordova yang sudah terbit dua edisi, hingga penelitian ini dilakukan belum memiliki ISSN. Kondisi ini mencerminkan masih lemahnya manajemen pengelolaan berkala ilmiah di lingkungan IAIN Mataram.

Sedangkan dari aspek substansi, berkala ilmiah yang secara spesifik mempublikasikan kajian kependidikan, sebagaimana tampak pada tabel di atas, hanya tujuh jurnal, masingmasing Jurnal Tasqif(Fakultas Tarbiyah), el-Hikmah (PAI), el-Midad (PGMI), Society (IPS), Biota (IPA), Beta (Matematika), dan el-Tsaqafah (PBA). Namun demikian, jurnal Ulumuna, Jurnal Penelitian Keislaman, dan Trsformatif juga memuat sejumlah artikel yang mengkaji tentang pendidikan Islam, namun dengan porsi yang sangat terbatas. Hal ini sebagai konskwensi dari perbedaan fokus kajian masing-masing berkala ilmiah. Fokus kajian berkala ilmiah tersebut sesuai dengan fakultas, jurusan, dan unit penerbit masing-masing. Keragaman ini mencerminkan keragaman keilmuan yang dikembangkan di lingkungan IAIN Mataram. Berbagai artikel pendidikan Islam yang dimuat pada berkala ilmiah tersebut dipilah sesuai dengan objek kajian, pendekatan, dan jenis studi yang dilakukan.

\section{Peta Kajian Pendidikan Islam Berdasarkan Objeknya: Kecenderungan Teoritis}

Bidikan objek kajian pendidikan Islam pada artikel-artikel ilmiah yang dipublikasikan sejumlah berkalah ilmiah di lingkungan IAIN Mataram masih mencerminkan dominannya aspek filsafat atau pemikiran pendidikan Islam. Mencermati sebaran artikel-artikel yang berhasil diidentifikasi, ada 15 artikel yang mengkaji aspek ini. Kecenderungan ini dapat dipandang masih kuatnya tradisi yang memposisikan teks sebagai sumber utama, dimana fokus kajiannya belum keluar dari aspek epistimologi dan ontologisnya yang abstrak. Hampir seluruh artikel yang masuk dalam kategori ini merujuk pada sejumlah litat ur yang direduksi ke dalam deskripsi konsep-konsep sesuai tema masing-masing, kecuali karya Usman yang berusaha masuk ke wilayah lebih empiris, yakni mengkaji pemikiran pendidikan Nahdlatul 
Wathan. ${ }^{12}$ Pola ini memang tidak dapat dihindari karena memang, wilayah filsafat umumnya merupakan kajian-kajian yang bersifat idealistik atau idealistik normatif.

Sementara di sisi lain, kajian-kajian yang lebih empiris - operasional yang bersentuhan langsung dengan pelaksanaan pendidikan Islam belum sepenuhnya diperhatikan sebagaimana halnya dengan objek filsafat di atas. Objek-objek kajian seperti manajamen pendidikan Islam, bersamaan dengan aspek subyek pendidikan (guru dan siswa) masing-masing hanya dimuat pada enam artikel. Diikuti sosiologi pendidikan Islam empat artikel, sejarah pendidikan Islam tiga artikel, media dan sumber pendidikan dua artikel, dan kurikulum pendidikan Islam dua artikel. Posisi yang paling tidak mendapat perhatian serius adalah objek psikologi pendidikan Islam, dan evaluasi pendidikan Islam.

Proporsi yang tidak seimbang garapan sejumlah artikel di atas, berimplikasi terhadap kurang dinamisnya pendidikan Islam dalam menjawab sejumlah persoalan empiris yang dihadapi. Jika artikel-ertikel tersebut bersikukuh dalam kondisi yang demikian, maka berkala ilmiah di lingkungan IAIN Mataram hanya akan menjadi wadah kumpulan toeri tanpa relavansi kontekstualnya dengan realitas pendidikan Islam. Beralasan, karena hingga kini belum ada produk ilmiah yang dipublikasan diberkala ilmiah di IAIN Mataram dapat diakses atau memiliki daya tarik untuk diakses oleh praktisi-praktisi pendidikan Islam secara rutin, seperti guru, kepala madrasah/sekolah, unsur Kemenag maupun pengawas. Hal ini disebabkan oleh dua kemungkinan: kemungkinan yang utama adalah produk ilmiah yang dipublikasikan melalui berkala ilmiah tersebut adalah hal-hal yang masih bersifat teoritis - konseptual, yang kadang-kadang jauh dari kebutuhan mereka. Sedangkan kemungkinan kedua adalah kurangnya sosialiasi dan distribusi berkala ilmiah kepada pihak-pihak yang bersentuhan langsung dengan pelaksana pendidikan Islam.

Objek kajian majanemen pendidikan Islam yang diharapkan dapat menjawab berbagai aspek pengelolalaan pendidikan Islam, masih didominasi kajian kepemimpinan. Lima dari enam artikel yang mengkaji aspek manajemen pendidikan Islam, merupakan kajian tentang kepemimpinan. Sedangkan yang menyangkut eksistensi lembaga-lembaga pendidikan (dalam berbagai jenisnya) diera kontemporer seperti networking, kemandirian, daya kompetitif, diversifikasi, program-progran unggulan, dan bebapa aspek lainnya, nampak luput dari perhatian. Dalam kenyataannya artikel-artikel sejenis ini tidak cukup memberikan informasi kualitatif sebagai dasar pengembangan dan pengelolaan pendidikan Islam kini dan masa depan. Artinya artikel-artikel tersebut belum merefleksikan persoalan-persoalan kontemporer yang dihadapi lembaga-lembaga pendidikan Islam dalam setting globalisasi saat ini.

\footnotetext{
${ }^{12}$ Usman, Pendidikan Nahdlatul Wathan di Lombok, Jurnal Penelitian Keislaman, Vol. 6, edisi 12009 , Lemlit IAIN Mataram
} 
Kondisi yang sama juga nampak pada kajian tentang subyek pendidikan, dimana lima artikel memiliki fokus kajian pada aspek guru. Sementara aspek peserta didik hanya dimuat dalam satu artikel yang mengkaji moral siswa ${ }^{13}$. Kajian terhadap subyek (pendidik) sebenarnya sudah mengarah perluasan berbagai sudut pandang, namun yang terasa masih kurang adalah kedalaman kajian dalam mendialogkan berbagai hasil pengamatan/temuan dengan pengembangan pendidikan Islam. Bahkan kuat kesan beberapa artikel tersebut masih deskriptif sosiologis.

Berbeda dengan kedua aspek di atas, dengan porsi yang sama, aspek strategi dalam pendidikan Islam yang dijadikan sebagai objek kajian cukup memberikan keragaman bidikan. Hal ini terlihat dari keragaman unsur yang dijadikan fokus, tidak hanya metode yang bersifat teknik, tetapi juga yang berifat operasional analitis. Dengan fokus pada aspek metode karya Akhmad Asy'ari dan Asari Nurwahidah, tentang penerapan metode inquiri pada mata pelajaran PAI, dan M. Azharudin dan Zohratun Fajriah, tentang penerapan metode role palying pada pembelajaran SKI, merupakan dua contoh artikel yang dari objek kajian secara spesifik operasional dan empiris dalam pembalajaran. Namun demikian kedua artikel tersebut terkesan deskriptif adoptif, karena kedua metode tersebut merupakan konsep yang diadopsi dari konsep Barat. Sedangkan corak yang cendrung lebih operasional analitis nampak pada artikel "Internalisasi Nilai-nilai Multikultural melalui PAI di Institusi Pendidikan"14, dan artikel "Pembelajaran Sejarah pada Institusi Pendidikan Madrasah" masing-masing ditulis M. Zaki.

Sedangkan kajian yang mengambil aspek sosiologi pendidikan Islam sebagai objek hanya empat artikel. Jumlah ini tidaklah memadai, mengingat problem utama yang dihadapi pendidikan Islam dewasa ini, justru bermuara pada ranah ini. Namun hasil pembacaan terhadap empat artikel dimaksud, hanya satu artikel yang memberikan jawaban yang relatif memadai atas sejumlah persoalan yang dihadapi. Artikel Mustain "Fenomena Kekerasan dan Upaya Penanganannya pada MA Negeri di Mataram"15, tidak hanya menyajikan sejumlah peroalan sosiologis yang dihadapi lembaga pendidikan Islam, juga solusi strategis at as persoalan yang dihadapi. Sedangkan tiga artikel lainnya ${ }^{16}$ masih bersifat deskriptif, belum sepenuhnya

\footnotetext{
${ }^{13}$ Lihat Nurul Yakin, Moral Keagamaan Siswa Madrasah Aliyah Negeri di Kota Mataram, Jurnal Tasqif, Vol. 4, Nomor 1, 2010

${ }^{14} \mathrm{M}$. Zaki, Internalisasi Nilai-nilai Multikultural melalui PAI di Institusi Pendidikan, Jurnal el-Hikmah, Vol. 4 Nomor 2, 2010.

${ }^{15}$ Musta'in, Fenomena Kekerasan dan Upaya Penanganannya pada MA Negri di Kota Mataram, Jurnal Penelitian Keislaman, Vol. 6, Nomor 1, 2009, Lembaga Penelitian IAIN Mataram.

${ }^{16}$ Artikel dimaksud adalah Zulkarnain, Interrelasi Pendidikan dengan Negara dalam Perspektif Islam, Jurnal Tasqif Vol. 8, Nomor 1, 2010; Sakdiah dan Ahmad Zuhdi, Peran Pendidikan Islam dalam Pembentukan Bangsa Indonesia yang Berkarakter, Jurnal Society, Edisi IV, 2011; dan Muchammadun, Tinjauan Psikologi Sosial pada Interaksi Kegiatan Belajar Mengajar, Strategi Pencitraan positif Jurusan PMI FDK IAIN Mataram, Jurnal Tasammuh, Vol. 8, Nomor 1, 2010, Fakultas Dakwah IAIN Mataram.
} 
mengungkap secara rediks dan kritis atas persoalan yang dikaji.

Sedangkan aspek psikologi dan evaluasi pendidikan Islam merupakan posisi yang terakhir dari objek yang diminati untuk dikaji. Dari 50 artikel yang berhasil dikumpulkan masingmasing aspek ini hanya muncul dalam 1 artikel, yaitu "Analisis Dua Potensi Manusia Perspektif al-Qur'an"17 yang ditulis Iwan Fitriani, walaupun masih dalam taraf sangat normatif. Psikologi pendidikan Islam nampak belum sepenuhnya dirasakan urgensinya sebagai salah satu bagian dalam konsep pendidikan Islam. Jika ditelisik, objek ini merupakan kajian yang sangat relevan dengan substansi pendidikan Islam yang lebih banyak mengembangkan aspek kepribadian (afektif-emosional). Ilmu psikologi memberikan informasi tentang kecenderungan yang paling dalam (dimensi batin) pada diri sesorang sebagai dasar yang menggerakkan prilaku orang.

\section{Peta Kajian Pendidikan Islam Berdasarkan Jenis Studi : Kecenderungan Penempatan Teks sebagai Realitas Utama}

Berbanding lurus dengan kecenderungan di atas, kajian pendidikan Islam yang dilakukan oleh dosen IAIN Mataram, dan dipublikasikan pada sejumlah berkala ilmiah di lingkungan IAIN Mataram menunjukkan dominannya kajian yang bersifat teoritis. Terdapat 31 artikel dari 50 artikel yang behasil diidentifikasi merupakan kajian-kajian teoritik. Kecenderungan kajian teoritik, mencerminkan dosen IAIN Mataram masih cenderung bergerak pada lingkaran "berwacana". Ini relevan dengan objek kajian yang dominan pada ranah pemikiran dan filsafat pendidikan Islam. Watak jenis kajian ini lazimnya adalah apa yang disebut Arif sebagai "memposisikan apa yang sudah ada" sebagai acuan otoritatif, sehingga penalaran yang dikembangkan selalu berada dalam "kemiripan" bahkan "pengulangan" dengan yang sudah ada. ${ }^{18} \mathrm{Hal}$ ini ia ungkapkan dari hasil studinya, bahwa corak ini juga merupakan kecenderungan umum dalam penulisan sejumlah buku-buku referensi pendidikan Islam. Mencermati muatan sejumlah artikel tersebut, apa yang diungkapkan Arif ini memiliki relevansi dengan kondisi pengkajian pendidikan Islam di IAIN Mataram.

Penempatan teks sebagai realitas, memberikan indikasi bahwa masih adanya asumsi bahwa referensi tertulis merupakan satu-satunya sumber penulisan karya ilmiah. Implikasinya, informasi yang disajikan masih berkutat pada antar kutipan satu dengan kutipan yang lain, tanpa dialog kritis dan memadai dengan realitas aktual empiris pendidikan Islam. Kenyataannya ini menurut Kailani tidak terlepas dari kecenderungan pola pikir umat Islam

\footnotetext{
${ }^{17}$ Iwan Fitriani, Analisis Dua Potensi Manusia Perspektif al-Qur'an ( Fujur vs Kufur, Kasabat vs Iktasabat, Kafirun vs Syaakiran, Jurnal el-Midad, Vol. 3, Nomor 1, 2011, Jurusan PGMI Fakultas Tarbiyah IAIN Mataram

${ }^{18}$ Mahmud Arif, Akar Involusi Konsep Pendidikan Islam Studi Pustaka atas Tipologi Enam Buku Referensi Pendidikan Islam, dalam Jurnal Penelitian Agama Lemlit UIN Sunan Kalijaga, Vol.XVII, No. 1, 2008
} 
pada umumnya masih berada dataran kemampuan ihsas al-musykilat (menyadari akan pelbagai masalah), namun belum mampu beranjak menuju dataran kemampuan tahdid wa tahlil al-musykilat (identifikasi dan memecahkan pelbagai masalah). ${ }^{19}$ Akhirnya, dalam hal tertentu nampak adanya upaya "pembenaran" antar literatur dalam sejumlah artikel yang di teliti. Kajian dalam jenis teoritik, melahirkan konsep pendidikan Islam berupa hasil pemikiran, perenungan, dan interpretasi para ahli yang diinspirasikan dari al-Qur'an dan As-Sunnah, baik tentang konsep ontologi, epistimologi, dan askiologi pendidikan Islam. Jenis studi ini cenderung bersifat idealistik dan normatif.

Di sisi lain publikasi ilmiah hasil penelitian para dosen IAIN Mataram nampak masih sangat sedikit dilakukan. Seperti yang disebutkan sebelumnya, dari 50 artikel yang diidentifikasi hanya 14 merupakan studi lapangan (field reseach) dan empat artikel merupakan studi pustaka (library research). Jenis studi empiris, melahirkan teori-teori kependidikan berdasarkan realitas praktik pendidikan. Para penulis tidak lagi melihat pendidikan Islam dari sudut yang ideal dan normatif, sebagaimana jenis teoritik di atas, tetapi melihat dari sisi yang senyatanya. Konsep dan teori dibangun dan dirumuskan berdasarkan tata kerja ilmiah digali dari fenomena proses, dan fakta pendidikan pada masyarakat Islam.

Kondisi ini tidak berbanding lurus dengan peningkatan jumlah penelitian di lingkungan IAIN Mataram setiap tahun. Sebagai bahan perbandingan, dalam rentang tiga tahun terakhir (2010-2012) setidaknya ada 157 judul penelitian yang didanai melalui DIPA (atau BLU) IAIN Mataram, ${ }^{20}$ baik yang secara langsung difasilatasi Lembaga Penelitian (Lemlit) maupun melalui Pusat Penelitian (Puslit) masing-masing Fakultas. Dengan kata lain bahwa jumlah penelitian dosen yang cenderung semakin meningkat, tidak memiliki implikasi terhadap peningkatan jumlah publikasi karya ilmiah hasil penelitian. Kondisi ini terjadi setidaknya dipenagruhi lemahnya regulasi yang mengatur kewajiban para peneliti (dosen) untuk mempublikasikan hasil penelitiannya pada berkala ilmiah.

Peta Kajian Pendidikan Islam Berdasarkan Pendekatan : Antara Pragmatisme, Idealisme dan Empirisme

Studi pendidikan Islam di IAIN Mataram mencerminkan dilema antara studi pragmatis operasional dengan normatif idealistik yang dapat berimplikasi terhadap semakin kuatnya antroposentrisme yang bercorak adoptif dan justifikatif di satu sisi, dan teosentris dengan

${ }^{19}$ Ibid. h. 27

${ }^{20}$ Pada tahun 2009 terdapat 20 judul penelitian, tahun 201047 judul, dan tahun 201185 judul. Peningkatan jumlah penelitian pada tahun 2011, karena didirikannya Pusat Penelitian di masing-masing fakultas, disamping Lemlit yang sejak lama mengelola penelitian. Lihat Lemlit IAIN Mataram, Profil Penelitian Dosen Lima Tahun Terakhir, dokumen dikutip September, 2012 
corak idealis yang cenderung apologi di sisi yang lain. Kondisi ini memiliki benang merah (walaupun tidak sama) dengan apa yang dikutip Muhaimin, bahwa studi keislaman di PTAI menghadapi tarik ulur antara studi keislaman dan pendekatan keagamaan, yang dapat berakibat pada tertindihnya misi keilmuan oleh misi keagamaan, atau sebaliknya. Studi keilmuan mengandaikan perlunya pendekatan kritis, analitis, empiris, historis. Sedangkan pendekatan keagamaan lebih menonjolkan sikap pemihakan, idealitas, bahkan sering diwarnai pembelaan bercorak apologis dan bersifat partikular subyektif. ${ }^{21}$

Kuatnya kecendorang kedua corak di atas, nampak dari sejumlah artikel ilmiah dosen yang dipublikasikan. Ada distance antara studi yang dilakukan pada tataran praktis operasional dengan dimensi teologis yang menjadi ruh pendidikan Islam. Pragmatis yang antroposentris nampak dalam artikel-artikel tersebut adalah konsep pendidikan umum, yang dominan dikembangkan dunia Barat. Bila dicermati, boleh jadi kecenderungan ini disebabkan semakin maraknya kebijkan pemerintah yang berkaiatan dengan pendidikan agama Islam di sekolah melalui kebijkan sertifikasi guru PAI sekolah dan Madrasah.

Berdasarkan analisis terhadap 50 artikel dosen IAIN Mataram dari aspek pendekatan yang digunakan, mengindikasikan adanya kecenderungan: Pertama, "pragmatisme adoptif" yaitu kajian yang berusaha mengambil produk intelektual Barat untuk kepentingan pendidikan Islam tanpa seleksi yang memadai. Asumsinya konsep-konsep Barat dipandang lebih maju, teruji, dan kontekstual. Asumsi ini menjadi dasar melakukan pembenaran bahwa jika pendidikan Islam ingin keluar dari keterbelakangannya saat ini atas Barat, maka berbagai konsep pendidikan Barat harus diterapkan dalam pengembangan pendidikan Islam. Hal ini nampak dalam beberapa artikel, misalnya artikel tentang "Evaluasi dalam Pembelajaran al-Qur'an"22 yang ditulis Ridwan, artikel "Kepala Madrasah sebagai Key the Person", ${ }^{23}$ yang ditulis Supardi, dan beberapa artikel lainnya yang memiliki pendekatan dan substansi kajian yang sama.

Dikhawatirkan, kecenderungan ini akan melahirkan apa yang diungkapkan Buchori ilmu pendidikan akan kehilangan jati diri, karena studi-studi yang dilakukan lebih concern pada persoalan-persoalan praktis operasional dan formal yang terdapat di sekolah/madrasah. ${ }^{24}$ Dalam konteks ini Muhaimin memberikan catatan bahwa formuliasi pendidikan Islam dapat diadopsi dari sistem pendidikan Barat kontemporer sejauh memiliki manfaat dan kegunaan dalam menjawab persoalan-persoalan pendidikan Islam. Namun dengan sifat yang demikian,

\footnotetext{
${ }^{21}$ Muhaimin, Wacana Pengembangan, h. 12

${ }^{22}$ Ridwan, Evaluasi dalam Pembelajaran al-Qur'an, Jurnal el-Midad, Vol. 3, Nomor 1, 2011, h. 1

${ }^{23}$ Supardi, Kepala Madrasah sebagai Key the Person, Jurnal Transformasi, Nomor 2, 2009, LPM IAIN Mataram.

${ }^{24}$ Mochtar Buchori, Ilmu Pendidikan dan Praktek Pendidikan dalam Renungan, Jogyakarta: Tiara Wacana, 1994.
} 
corak ini dalam batas tertentu dapat "mengaburkan" kalau bukan "menindih" konsep dan karakter pendidikan Islam. Menurut Muhamin, hal ini merupakan fenomena umum penulisan konsep-konsep pendidikan Islam di lingkungan PTAI. ${ }^{25}$

Sementara penggunaan pendekat an deskriptif empiris masih berkutat pada penjelalsan atas berbagai fakta di lapangan, masih menyisakan peroalan yang dari apa yang ditemui. Selain adanya kecenderungan kajian tanpa sentuhan niali-nilai esensial dari ajaran Islam, juga upaya inovatif untuk menjawab permasalahan yang berhasil ditemui belum memberikan kontribusi baik secara praktis maupun keilmuan. Pendekat an deskriptif empiris ini umumnya tercermin dari artikel-artikel hasil studi lapangan (field research) baik secara kualitatif maupun kuantitatif. Misalnya artikel hasil penelitian yang dilakukan Nurul Yakin, Achsanudian dan Fauziyah, ${ }^{26}$ Musari dan Bediawati, ${ }^{27}$ dan beberapa artikel lainnya yang memiliki kecenderungan yang sama. Sebagai contoh artikel Nurul Yakin memiliki hasil kajian yang cukup memadai dengan tinjauan beberapa aspek fenomena moralitas siswa Madrasah di Kota Mataram, ${ }^{28}$ namun kekayaan temuan tersebut, tanpa tawaran solusi yang inovatif, sehingga terasa sebatas pengungkapan fakta, bukan menjawab persoalan praktis pendidikan Islam.

Pada waktu yang bersamaan studi yang bercorak teosentris yang mewarnai pendekatan dalam kajian pendidikan Islam di IAIN Mataram juga nampak dalam sejumlah artikel yang dipublikasikan. Kondisi ini mencerminkan adanya kecenderungan kedua, noramtifidealistik, yang cenderung kurang kontekstual dalam menjawab sejumlah persoalan nyata yang dihadapi dalam pengembangan pendidikan Islam. Membaca beberapa artikel dosen IAIN Mataram yang dipublikasikan pada berkala ilmiah, corak ini tidak hanya berusaha menempatkan keunggulan doktrin Islam dalam pendidikan, dalam aspek tertentu juga menegasikan dan melakukan distingsi dengan konsep pendidikan umum (Barat). Sebut saja artikel Asnawi, tentang "Konsep Belajar Tuntas al-Ghazali", ${ }^{29}$ artikel Ridwan tentang "Landasan Pendidikan Islam", artikel Muhsinin Hasni tentang "Pendidikan Humanisme Sekuler versus Humanisme Qur'ani", ${ }^{30}$ artikel Ahmad Asy'ari tentang "Pemikiran Pendidikan

${ }^{25}$ Muhaimin, Wacana Pengembangan, hal. 117-118

${ }^{26}$ Achsanuddin dan Fauziyah, Penerapan KBK dalam upaya meningkatkan Aktivitas Pembelajaran pada Mata Pelajaran PAI di SMAN 7 Mataram, Jurnal el-Hikmah, Nomor 2, 2009), Jurusan PAI Fakultas Tarbiyah IAIN Mataran

${ }^{27}$ Musari dan Bediawati, Strategi Guru PAI dalam Membina Akhlak Siswa di SMPN 1 Praya Timur Lombok Tengah 2008/2009, Jurnal el-Hikmah, Nomor 2, 2009), Jurusan PAI Fakultas Tarbiyah IAIN Mataran, h. 90

${ }^{28}$ Nurul Yakin, Moral Keagamaan Siswa Madrasah Aliyah Negeri di Kota Mataram, Jurnal Tasqif, Vol. 4, Nomor 1,2010

${ }^{29}$ Asnawi, Pemikiran al-Ghazali tentang Belajar Tuntas, Jurnal Penelitian Keislaman, Vol 6, No. 1 Desember 2009, Lemlit IAIN Mataram, h. 4

${ }^{30}$ Muhsinin Hasni, Menyoal Humanisme Pendidikan Humanisme Sekuler versus Humanisme Qur'ani, Jurnal Tasqif, Vol. 4. Nomor 1, 2010. 
Muhammad Abduh", ${ }^{31}$ dan beberapa artikel lainnya. Dianggap kurang kontekstual, artikel pendidikan Islam yang dimuat pada berkala ilmiah tersebut lebih dominan menggunakan pendekatan normatif idealistik, dengan objek studi pemikrian/filsafat pendidikan, dan jenis studi teoritik. Hal-hal yang bersifat praktis operasional tidak mendapat apresiasi yang memadai dalam pola studi ini.

Bila dicermati lebih jauh, tradisi keilmuan normarif idealis bermaksud mengusung alQur'an dan Hadits, dan pemikiran ulama klasik sebagai jawaban ideal terhadap persoalanpersoalan yang dihadapi pendidikan Islam dewasa ini. Kecenderungan ini menjadi dasar jugment akan supremasi doktrin-doktrin Islam atas produk intelektualnya atas Barat dan modernitas dengan segala produk intelektualnya. Kecenderungan ini menurut Mahmud Arif, merupakan tradisi normatif idealistik yang ditandai dengan ciri eksternalisasi Islam, yakni keinginan untuk menampilkan keunggulan ajaran Islam dalam bidang pendidikan. Hanya saja penalaran yang digunakan masih bersifat "apologi" atau "pengiman" bukan "pengkaji" 2 sehingga argumen dan elaborasinya masih terbatas pada kerangka membangun kesepahaman internal (sesama umat Islam) yang terkadang terkesan apologetis.

Jika dilakukan spesifikasi berdasarkan keragaman artikel yang diidentifikasi, maka pendekatan idealis ini sebetulnya dapat dipetakan dalam dua tipologi, yaitu normatif idealistik, sebagaimana di jelaskan di atas, dan idealis kritis, yaitu mengkaji konsep-konsep pendidikan Islam berlandaskan al-Qur' an, Hadits dan pendapat para ulama, seraya mengkritisi fenomena empiris praktik pendidikan Islam. Kecenderungan ini nampak dari artikel Abdul Fattah tentang "Mengorkestrasi UIN sebagai Institusi Pendidikan Islam Integratif". ${ }^{33}$ Sebagaimana dijelaskan pada bagian sebelumnya, artikel ini memuat sejumlah identifikasi dan analisis terhadap persoalan empiris pengembangan keilmuan pada institusi pendidikan Islam, seraya menganalisis solusi ideal dalam menjawab persoalan tersebut. Senafas dengan artikel ini, artikel "Pendidikan Islam: Media Pembentukan Citra Ilahi" ${ }^{34}$ yang ditulis Abdul Quddus dan Lestari, juga menunjukkan muatan substansi yang sama.

Di samping beberapa corak di atas, kecenderungan lain yang juga muncul dalam kajian pendidikan Islam pada berkala ilmiah di IAIN Mataram adalah corak eklektif, yaitu mengambil suatu pemikiran atau konsep yang terbaik dari teori pendidikan yang berkembang

${ }^{31}$ Ahmad Asy’ari, Pemikiran Pendidikan Muhammad Abduh tentang Modernisasi Pendidikan Islam, Jurnal Tasqif, Vol. 5, Nomor 2, 2011

${ }^{32}$ Mahmud Arif, Akar Involusi, h. 22

${ }^{33}$ Abdul Fattah, Mengorkestraasi UIN sebagai Instit usi Pendidikan Islam Integratif Nondikotomis, Jurnal el-Hikmah, Vol. 5 Nomor 2, 2011, Jurusan PAI Fakultas Tarbiyah IAIN Mataram, h. 119-122

${ }^{34}$ Abdul Quddus dan Lestari, Pendidikan Islam: Media Pembentukan Manusia Citra Ilahi, Jurnal el-Himah, Vol. 5, Nomor 1, 2011, Jurusan PAI Fakultas Tarbiyah IAIN Mataram 
saat ini (Barat) secara selektif dan kritis, sejauh memimiliki relevansi dengan ajaran Islam, seraya mengembangkan konsep pendidikan Islam yang bersumber dari ajaran Islam. Kecenderungan ini dalam batas tertentu dapat dikatakan merupakan gabungan dari corak idealis dan corak pragmatis, sehingga corak cenderung menjadi pendekatan alternatif dalam studi-studi pendidikan Islam saat ini. Walaupun sudah ada yang bercorak eklektif, tetapi ini masih sangat sedikit dilakukan. Dari 50 artikel yang diidentifikasi setidaknya corak ini muncul dalam dua artikel, yaitu artikel Ahmad Sulhan tentang "PAI dan Teknologi Informasi dan Komunikasi", ${ }^{35}$ dan Abdulloh Fuadi tentang "Pesantren dan perpustakaan". ${ }^{36}$ Pada kedua artikel ini, penulisnya berusaha meyakinkan pembaca pentingnya inovasi yang ada di Barat, seraya membangun argumen normatif dan sosilologis dari ajaran Islam, dan memperkuat karakter pendidikan Islam. Tentu ini berbeda dengan kecenderungan pragmatis adoptif, dimana pengambilan konsep pendidikan pada umumnya tanpa menunjukkan dasar normatifnya dan relevansinya dengan pendidikan Islam.

Pemaknaan di atas, relevan dengan pemetaan yang dilakukan Abdul Mudjib dan Jusuf Muzakkir. Sebagaimana dikutip pada bagian sebelumnya, Abdul Mudjib dan Jussuf Muzakkir mencoba memetakan kajian pendidikan Islam dalam tiga kecenderungan, ${ }^{37}$ yaitu: pertama, corak adoptif, yaitu mengambil konsep dan teori Barat sebagai konsep dan dasar pemikiran pengembangan pendidikan Islam. Corak ini mengasumsikan bahwa tidak salahnya jika pemikir muslim meminjam atau bahkan menemukan kebenaran dari pemikiran Barat; kedua, corak idealistis, yaitu mengambil dan mengembangkan konsep dan teori pendidikan Islam hanya berlandaskan pada al-Qur'an dan hadits, dan pemikiran para tokoh muslim, dan berusaha menjauhkan pemikiran yang bersumber dari Barat. Corak ini mengasumsikan bahwa Islam merupakan sistem ajaran yang universal dan kompherensif. Tidak satu pun persoalan termasuk persoalan pendidikan yang luput dari jangkauan ajaran Islam.

Untuk menjembatani kedua corak di atas, maka Abdul Mudjib dan Jusuf Muzakkir menwawarkan corak ketiga, yaitu corak eklektik, yaitu mengambil suatu pemikiran atau konsep yang terbaik dari teori Barat secara selektif dan kritis, sejauh memimiliki relevansi dengan ajaran Islam, seraya mengembangkan konsep pendidikan Islam yang bersumber dari ajaran Islam.

${ }^{35}$ Ahmad Sulhan, Inovasi Sistem Pembelajaran PAI Berbasis TIK: Suatu Model Pembelajaran PAI Bereksploratif dalam Menjelajahi Kebutuhan Global, Jurnal Tatsqif, Vol. 9, Nomor 2, 2011, Fakultas Tarbiyah IAIN Mataram, h, 159-175

${ }^{36}$ Abdulloh Fuadi, Perpustakaan: Sebuah Keniscayaan Unsur Baru Dunia Pesantren, Jurnal el-Hikmah, Vol. 5, Nomor 2, 2011, Jurusan PAI Fakultas Tarbiyah IAIN Mataram, h, 25-45

${ }^{37}$ Abdul Mujib dan Jusuf Mudzakkir, Ilmu Pendidikan, h. 3-6 
Eklektivitas kajian pendidikan Islam menggaris bawahi pentingnya kritik yang memadai sebagai frame dalam melakukan eksplorasi dan interaksi antara kepentingan pragmatis dengan ruh teologis (idealis) pendidikan Islam. Upaya ini diharapkan produk akademis dalam bentuk publikasi ilmiah para dosen di IAIN Mataram dalam aspek pendidikan Islam tidak kehilangan relevansinya. Namun, merujuk pada sebaran artikel pada berkala ilmiah yang disebutkan di atas, paradigma ini belum banyak diapresiasai secara signifikan oleh para penulis pendidikan Islam yang diteliti.

Kondisi di atas, memperkuat temuan Mahmud atas sejumlah penulisan buku-buku pendidikan Islam. Ia mentengarai adanya kecenderungan umum buku-buku referensi pendidikan Islam masih belum beranjak jauh dari penalaran normatif-reproduktif. ${ }^{38}$ Menurutnya, hal ini ditandai oleh adanya kecenderungan pola pembahasan tekstual, analogis, dan deklaratif, sehingga terasa miskin relevansi empirik-kontekstual, karena pusat perhatiannya terletak pada teks, pendapat sebelumnya, dan semangat "mendedahkan" keunggulan norma Islam. Konidisi ini menurutnya, melahirkan pola kajian : pertama, pola hubungan justifikatif antar sesama buku referensi; kedua, pendekatan terhadap wahyu yang normatif; dan ketiga, pendekatan sejarah yang idealistik.

Berdasarkan analisis di atas, maka penting untuk mempertimbangkan dan mengembangkan paradigma teoantoposentris, suat u paradigma yang mencoba menjembatani kebutuhan pragmatis pendidikan Islam dengan idealisme normatif ajaran Islam. Paradigma ini menghendaki agar konsep pendidikan Islam yang dikembangkan memiliki relevansi normatif dengan pelaksanaan pendidikan di lapangan. Relevansi normatif ini mengasumsikan bahwa pendidikan Islam memang tidak bisa dilepaskan dari dialektika dinamis dengan ajaran Islam, namun tidak dalam pengertian dogmatik yang menempatkan ajaran Islam sebagai rujukan yang mengikat, dimana kreativitas intelektual cenderung dibatasai melalui ketundukan pada pemehaman literal dan rigid.

Memperhatikan realitas kajian pendidikan Islam di atas, nampaknya belum bergerak dari apa yang digambarkan Azra tahun 2009. Setelah mengkaji beberapa referensi pemikiran dan teori pendidikan Islam, Azra menyimpulkan bahwa pola kajian dan pemikiran dan teori kependidikan Islam di Indonesia memiliki beberapa kecenderungan ${ }^{39}$ : pertama, mendekatinya dengan sangat doktrinal, normatif, dan idealistik; kedua, mengadopsi filsafat, pemikiran dan teori kependidikan Barat, tanpa kritisme yang memadai, bahkan terjadi pengambilan mentah-mentah; ketiga, memberikan legimitasi terhadap pemikiran dan dan filsafat Barat

\footnotetext{
${ }^{38}$ Mahmud Arif, Akar Involusi Konsep Pendidikan, hal. 30

${ }^{39}$ Azyumardi Azra, Pendidikan Islam, h. 91
} 
dengan ayat al-Qu'an dan hadits tertentu, yang belum tentu kontekstual dan relevan dengan konsep Islam; dan keempat, konsep kependidikan Islam atau yang relevan dengannya, yang dikembangkan para ulama, pemikir dan filosof muslim sedikit sekali diungkap dan di bahas.

\section{SIMPULAN}

Berdasarkan hasil analisis terhadap data temuan, maka simpulan penting dalam studi ini: pertama, dari aspek objek studi, kajian pendidikan Islam pada berkala ilmiah di IAIN Mataram mencerminkan dominannya aspek filsafat atau pemikiran pendidikan Islam sebagai objek kajian. Kecenderungan ini dapat dipandang masih kuatnya tradisi yang memposisikan teks sebagai sumber utama, dimana fokus kajiannya belum keluar dari aspek epistimologi dan ontologisnya yang abstrak. Sementara di sisi lain, kajian-kajian yang lebih empiris operasional yang bersentuhan langsung dengan pelaksanaan pendidikan Islam, seperti manajamen pendidikan, subyek pendidikan (guru dan siswa), sosiologi pendidikan, sejarah pendidikan, media dan sumber pendidikan, kurikulum pendidikan, psikologi pendidikan, dan evaluasi pendidikan Islam, belum sepenuhnya diperhatikan sebagaimana halnya dengan objek filsafat pendidikan Islam.

Kedua, sejalan dengan objek kajiannya, dari segi jenis studi, konsep pendidikan Islam yang dipublikasikan pada berkala ilmiah di IAIN Mataram, menunjukkan masih kuatnya kecenderungan kajian teoritis, disusul penelitian lapangan (field reseach), dan kajian pustaka (library reseach). Adanya kecenderungan ini mencerminkan bahwa studi dan publikasi konsep pendidikan Islam yang dilakukan dosen IAIN Mataram belum bergerak lebih jauh dari lingkaran "wacana" dengan memposisikan teks sebagai sumber otoritatif (utama). sementara publikasi hasil-hasil studi empiris belum banyak dilakukan.

Ketiga, paralel dengan kedua aspek di atas, dilihat dari segi pendekatan yang digunakan, kecenderungan pola kajian pendidikan Islam dosen IAIN Mataram, dapat dipilah dalam beberapa corak: (a). Corak pragmatis, yaitu kajian yang lebih mengutamakan aspek-aspek praktis dan kegunaannya dalam pendidikan Islam, baik yang bersifat adoftif maupun justifikatif, (b) corak Idealis, yaitu kajian yang menempatkan al-Qur'an dan Hadits dan pemikiran klasik dalam posisi yang lebih unggul untuk menjelaskan (bukan menjawab) sejumlah aspek/persoalan pendidikan Islam, baik secara idealis normatif maupun idealis kritis; (c) corak eklektif, kajian mengambil suatu pemikiran atau konsep yang terbaik dari teori pendidikan yang berkembang saat ini (Barat) secara selektif dan kritis, sejauh memimiliki relevansi dengan ajaran Islam, seraya mengembangkan konsep pendidikan Islam yang bersumber dari ajaran Islam. Kecenderungan ini dalam batas tertentu dapat dikatakan merupakan gabungan dari corak idealis dan corak pragmatis; dan (d) corak deskriptif empiris, 
mengkaji fenomena empiris pendidikan Islam tanpa memberikan kontribusi yang memadai, baik secara keilmuan maupun kepentingan praktis pendidikan Islam.

\section{Daftar Pustaka}

Arif, Mahmud, Akar Involusi Konsep Pendidikan Islam Studi Pustaka atas Tipologi Enam Buku Referensi Pendidikan Islam, dalam Jurnal Penelitian Agama Lemlit UIN Sunan Kalijaga, Vol.XVII, No. 1, 2008

Ardana, dkk. Metodologi Penelitian Pendidikan, Malang, UMN, 2001

Azra, Azyumardi, Pendidikan Islam Tradisi dan Modernisasi Menuju Milenium Baru, Jakarta, Logos, 1999

Fadjar, Malik, Pengembangan Pendidikan Islam yang Menjanjikan Masa Depan, dalam Edukasi, Jurnal Penelitian Pendidikan Agama dan Keagamaan, Vol. 2, No. 1, 2004, Puslitbang-Diklat Keagamaan, Departemen Agama RI

Kholis Setiawan, Nur, Etika Terbitan Berkala Ilmiah, Makalah disampaikan pada Penataran dan Lokakarya Manajemen Berkala Ilmiah, di Yogyakarta, 2011

Krippendorff, Klaus, Analisis Isi: Pengantar Teori dan Metodologi, terj. Farid Wajidi, cet. 2, Jakarta: Raja Grafindo Persada, 1993

McMillan, James H. dan Sally Schumacher, Research in Education: A Conceptual Introduction, New York: Longman, 2001

Muhadjir, Noeng, Metodologi Penelitian Kualitatif, Yogyakarta: Rake Sarasin, 1995 Muhaimin, Wacana Pengembangan Pendidikan Islam, Surabaya, Pustaka Pelajar, 2003 Mujib, Abdul dan Jusuf Mudzakkir, Ilmu Pendidikan Islam, Jakarta, Kencana, 2006 Nata, Abuddin, Metodologi Studi Islam, Cet. 18, Jakarta, Raja Grafindo Persada, 2011 Permendiknas No. 22 tahun 2011, Tentang Terbitan Berkala Ilmiah , No. 22 tahun 2011, Tentang Terbitan Berkala Ilmiah

Robby Hidayat, Heuristik Penulisan Artikel Seni dan Desain dalam Jurnal, Makalah Semiloka dan Pameran Nasional Strategi Penerbitan Jurnal Nasional Bidang Seni dan Desain, Universitas Negeri, 2001.

Supardi, Identifikasi Masalah Penelitian sebagai Dasar Penetapan Kajian Skripsi Mahasiswa Fakultas Tarbiyah IAIN Mataram, Laporan Penelitian, Lemlit IAIN Mataram, 2009

Taufik, H.M, Kebijakan Pengembangan Berkala Ilmiah di IAIN Mataram, Makalah disampaikan pada Lokakarya Peningkatan Mutu dan Penyuntingan Berkala Ilmiah, Jurnal Penelitian Keislaman IAIN Mataram, 2011

Triwulan, Materi Dasar Penulisan Jurnal Ilmiah, disampaikan pada PENLOK Penelitian Dosen Muda dan Kajian Wanita, di Mataram, DP2M, 2006 
Tafsir, Ahmad, Ilmu Pendidikan dalam Perspektif Islam, Bandung, Remaja Rosda Karya, 1992

Tobroni, Pendidikan Islam Paradigma Teologis, Filosofis dan Spiritual, Malang, UMM Pres, 2008

Asnawi, Pemikiran al-Ghazali tentang Belajar Tuntas, Jurnal Penelitian Keislaman, Vol 6, No. 1 Desember 2009, Lemlit IAIN Mataram

Zulkarnain, Pendidikan dan Pengajaran dalam Persepektif al-Qu'an, el-Midad, Vol. 3 Nomor 2, 2011

Iwan Fitriani, Analisis Dua Potensi Pokok Manusia Perspektif al-Qur'an (Fujur vs Kufur, Kasabat vs Iktasabat, kafiran vs Syaakiran), Jurnal el-Midad, Vol. 3 Nomor 1, 2011

Ridwan, Evaluasi dalam Pembelajaran al-Qur'an, Jurnal el-Midad, Vol. 3, Nomor 1, 2011

Supardi, Kepala Madrasah sebagai Key the Person, Jurnal Transformasi, Nomor 2, 2009, LPM IAIN Mataram.

Ahmad Sulhan, Inovasi Sistem Pembelajaran PAI Berbasis TIK: Suat u Model Pembelajaran PAI Bereksploratif dalam Menjelajahi Kebutuhan Global, Jurnal Tatsqif, Vol. 9, Nomor 2, 2011, Fakultas Tarbiyah IAIN Mataram

Abdulloh Fuadi, Perpustakaan: Sebuah Keniscayaan Unsur Baru Dunia Pesantren, Jurnal elHikmah, Vol. 5, Nomor 2, 2011, Jurusan PAI Fakultas Tarbiyah IAIN Mataram

Usman, Menalar Pendidikan Islam Masa Awal, Jurnal el-Hikmah, Vol. 5 Nomor 1, 2011, Jurusan PAI Fakultas Tarbiyah IAIN Mataram

Baehaqi, Menoropong Realitas Pendidikan Islam Zaman Rasulullah, Sahabat, Bani Umayyah dan Bani Abbasiyah, Jurnal el-Hikmah, Vol. 3 Nomor 1, 2009, Jurusan PAI Fakultas Tarbiyah IAIN Mataram

Abdul Fattah, Mengorkestraasi UIN sebagai Institusi Pendidikan Islam Integratif Nondikotomis, Jurnal el-Hikmah, Vol. 5 Nomor 2, 2011, Jurusan PAI Fakultas Tarbiyah IAIN Mataram

M. Zaki, Pembelajaran Sejarah pada Institusi Pendidikan Madrasah, Jurnal Society Edisi III, 2010, Jurusan IPS Fakultas Tarbiyah IAIN Mataram

Abdul Quddus dan Lestari, Pendidikan Islam: Media Pembentukan Manusia Citra Ilahi, Jurnal el-Himah, Vol. 5, Nomor 1, 2011, Jurusan PAI Fakultas Tarbiyah IAIN Mataram Achsanuddin dan Fauziyah, Penerapan KBK dalam upaya meningkatkan Aktivitas Pembelajaran pada Mata Pelajaran PAI di SMAN 7 Mataram, Jurnal el-Hikmah, Nomor 2, 2009), Jurusan PAI Fakultas Tarbiyah IAIN Mataran 
Akhmad Asyari, Upaya mengatasi keterlambatan Kemampuan Membaca dan Menulis alQur'an Siswa Kelas II SDN Gantang Pujut Tahun Pelajaran 2009/2010, Jurnal elHikmah, Nomor 2, 2010), Jurusan PAI Fakultas Tarbiyah IAIN Mataran

Musari dan Bediawati, Strategi Guru PAI dalam Membina Akhlak Siswa di SMPN 1 Praya Timur Lombok Tengah 2008/2009, Jurnal el-Hikmah, Nomor 2, 2009), Jurusan PAI Fakultas Tarbiyah IAIN Mataran

Baehaqi dan Salbiyah, "Peran Serta Guru PAI dalam Mengatasi Konflik dan Prustasi pada Siswa di SMPN 2 Lembar, Tahun Pelajaran 2009/2010"

Nurul Yakinah dan Turaya, "Hubungan antara Frekwensi Kunjungan ke Perpustakaan dengan Prestasi Siswa pada Mata Pelajaran PAI di SMPN Palibelo Bima Tahun Pelajaran 2005/2006", Jurnal el-Hikmah Vol. 3, Nomor 2, 2009

Usman, Pendidikan Nahdlatul Wathan di Lombok, Jurnal Penelitian Keislaman, Vol. 6, edisi 1 2009, Lemlit IAIN Mataram

Lihat Nurul Yakin, Moral Keagamaan Siswa Madrasah Aliyah Negeri di Kota Mataram, Jurnal Tasqif, Vol. 4, Nomor 1, 2010

M. Zaki, Internalisasi Nilai-nilai Multikultural melalui PAI di Institusi Pendidikan, Jurnal el-Hikmah, Vol. 4 Nomor 2, 2010.

Musta'in, Fenomena Kekerasan dan Upaya Penanganannya pada MA Negri di Kota Mataram, Jurnal Penelitian Keislaman, Vol. 6, Nomor 1, 2009, Lembaga Penelitian IAIN Mataram.

Zulkarnain, Interrelasi Pendidikan dengan Negara dalam Perspektif Islam, Jurnal Tasqif Vol. 8, Nomor 1,2010

Sakdiah dan Ahmad Zuhdi, Peran Pendidikan Islam dalam Pembentukan Bangsa Indonesia yang Berkarakter, Jurnal Society, Edisi IV, 2011

Muchammadun, Tinjauan Psikologi Sosial pada Interaksi Kegiatan Belajar Mengajar, Strategi Pencitraan positif Jurusan PMI FDK IAIN Mataram, Jurnal Tasammuh, Vol. 8, Nomor 1, 2010, Fakultas Dakwah IAIN Mataram.

Iwan Fitriani, Analisis Dua Potensi Manusia Perspektif al-Qur'an ( Fujur vs Kufur, Kasabat vs Iktasabat, Kafirun vs Shakiran, Jurnal el-Midad, Vol. 3, Nomor 1, 2011, Jurusan PGMI Fakultas Tarbiyah IAIN Mataram

Lemlit IAIN Mataram, Profil Penelitian Dosen Lima Tahun Terakhir, dokumen dikutip September, 2012

Mochtar Buchori, Ilmu Pendidikan dan Praktek Pendidikan dalam Renungan, Jogyakarta: Tiara Wacana, 1994. 